\title{
金属材料リサイクルフローの最適化手法の開発と アルミニウムへの応用
}

\author{
山田宏之* 畑山博 樹* 醍醐市朗松野泰也足立芳寛
}

東京大学大学院工学系研究科マテリアル工学専攻

J. Japan Inst. Metals, Vol. 70, No. 12 (2006), pp. 995-1001

(C) 2006 The Japan Institute of Metals

\section{Optimization Method for Metal Recycling System and Its Application to Aluminum Recycling Flow in Japan}

Hiroyuki Yamada*, Hiroki Hatayama*, Ichiro Daigo, Yasunari Matsuno and Yoshihiro Adachi

Graduate School of Engineering, The University of Tokyo, Tokyo 113-8656

In this paper an optimization method for metal recycling flow has been developed. The method adopts a linear programming to optimize the recycling of material, in which the concentrations of two or more tramp elements in the scraps are considered.

The method was applied to analyze the aluminum recycle flow in Japan in 2003 . It was found that the $65 \%$ of virgin material could be substituted by recycled material.

When the use of casting from end-of-life vehicles (ELV) is expanded, $\mathrm{Cu}$ included in the aluminum casting will be predominant restriction for the reduction of virgin material. The other side, when the use of aluminum scrap from construction is expanded, the maximum recyclable amount of aluminum scrap is dominated by $\mathrm{Mn}$ concentration in the scrap.

(Received July 20, 2006; Accepted October 10, 2006)

Keywords: aluminum, recycle flow, linear programming, optimization, tramp element

\section{1. 緒言}

アルミニウム等の金属材料は，用途に応じて様々な元素が 添加され，多くは合金として用いられる。これらの合金のリ サイクルを行う際には，用途に応じてリサイクル材の成分調 整が不可欠となる。しかしながら，合金として製造する際に 添加された元素，あるいは使用済久製品から回収する祭に混 入した元素のうち, 除去することが困難な元素(トランプエ レメント)の成分調整は，様々な成分濃度を持つ材料を適切 に混合すること(希釈)によって行うことになるため，その材 料のリサイクルは制限される. また, リサイクル時にトラン プエレメントが混入するような場合には, リサイクルが繰り 返されることによってトランプエレメントが濃化し，リサイ クル材の使用が困難になる可能性が指摘されている1).

鋼材リサイクルに抢ける銅の混入と濃化による, 将来の鉄 スクラップリサイクルの限界ついては, 著者らが, 銅濃度を 「質」の尺度としたピンチ解析を適用し, 解析を行ってい $ろ^{2)}$.

アルミニウムに拈いては，主として経済的な理由で除去困 難な元素が複数存在する ${ }^{3,4)}$. また，一般にトランプエレメ ント濃度の低い圧延材から, 高い濃度を許容する鋳物・ダイ カストへのカスケード型リサイクルが行われている. 圧延材
の需要が増加傾向にあることを背景として, 圧延材から圧延 材へのリサイクルの必要性も指摘されている5)が, トランプ エレメントの除去が, 技術的, 経済的に困難である上に, 現 時点では鋳物・ダイカストの需要が十分大きいことから, 飲 用缶以外には一般的に行われていない.

本研究では, 複数のトランプエレメントを同時に扱う素材 のリサイクルフロー最適化の手法を開発する。 また，これを 我が国のアルミニウムのリサイクルフローに適用したケース スタディを行い，アルミニウムのバージン材 (新地金)投入量 の削減可能性を検討する.

\section{2. 解 析 方 法}

\section{1 考慮すべきトランプエレメントが一つ場合のリサイク ルフロー最適化}

著者らは，銅をトランプエレメントとし，銅濃度を「質」 の尺度として鉄スクラップリサイクルにピンチ解析法を適用 し, 最大リサイクル可能量の解析を行っている. ピンチ解析 とは，量と質から物質の需給バランスを解析する方法であ り，プラントやコンビナートでの水利用システムの最適化等 に用いられている6,7) . 銅をトランプエレメントとした例の ように, トランプエレメントが一つの場合は, 図解法による 解析が可能である ${ }^{8)}$.

\footnotetext{
* 東京大学大学院生 (Graduate Student, The University of Tokyo)
} 


\section{2 考慮すべきトランプエレメントが複数ある場合のリサ イクルフロー最適化モデル}

考慮すべきトランプエレメントが複数あって，それらを同 時に扱う場合は, 図解法によって解析することはできない. 数学的な解法が必要となる. 本研究では, 線形計画法を適用 した解析を行った。

線形計画法は，1次不等式で表される制約条件の下で，目 的関数の最大化(あるいは最小化)を満たす最適解を見つける 手法であり，様々な分野で応用されている ${ }^{9,10)}$. 本研究で は，国内に打ける素材のリサイクルフローの最適化に線形計 画法を適用した. 目的関数と制約条件は，以下のように考え る.

（a）目的関数：材料使用に関する環境負荷やコストの最小 化

(b) 制約条件 :

(i) 「供給量」ミ「需要側での材料使用量」

(ii) 「生産量 $\rfloor \geqq$ 需要量」

(iii)「生産材のトランプエレメント濃度」ミ「需要側材料 のトランプエレメント許容濃度」

(iv)「生産材のトランプエレメント濃度」ミ「需要側材料 のトランプエレメント必要濃度」

\section{3 定式化}

供給される材料(供給材)の種類が $\mathrm{i}$ 種あって, それらの供 給材を混合して $\mathrm{j}$ 種の生産材を製造するときの最適化条件を 求める。 また，解析にあたっては， $\mathrm{k}$ 種のトランプエレメン トを扱う (Fig. 1).

以下に, 線形計画法の解析に抢ける定式化の手順を示す.

\subsection{1 リサイクルフローのモデル化}

供給材の供給量, 需要量を設定する. あわせて, 供給材の トランプエレメントの成分濃度と, 需要側のトランプエレメ ント濃度の許容範囲を設定する。この許容範囲は，上限值， 下限值あるいはいずれか一方を設定する.

\subsection{2 目的関数の定式化}

$s_{\mathrm{i}}$ は供給材 $\mathrm{i}$ の供給量, $d_{\mathrm{j}}$ は生産材 $\mathrm{j}$ の需要量, $c$ は供給あ るいは消費 1 単位毎に必要な負担を表す定数とすると, 目 的関数 $f\left(s_{\mathrm{i}}, d_{\mathrm{j}}\right)$ を式 (1)のように表すことができる.

最適化の目的をコスト最小とする場合は, $c$ に供給, 消費 に要するコストを, 環境負荷誘発量の最小化を目的とする場 合は，それぞれに要する環境負荷誘発量を設定する。

$$
f\left(s_{\mathrm{i}}, d_{\mathrm{j}}\right)=\sum_{i=0}^{m} c_{\mathrm{i}} s_{\mathrm{i}}+\sum_{j=0}^{n} c_{\mathrm{j}} d_{\mathrm{j}}
$$

\subsection{3 制約条件の定式化}

\section{(i)「供給量」ミ「需要側での材料使用量」}

需要量以上の供給量が確保されるように条件を設定する.

$$
\sum_{i=0}^{m} s_{\mathrm{i}} \geq \sum_{j=0}^{n} d_{\mathrm{j}}
$$

\section{(ii) 「生産量」ミ「需要量」}

生産材 $\mathrm{j}$ は，供給材の混合により生産される。ここで $p$ は, 生産材の生産量であり, 混合した供給材の和に等しい。 需要量を上回る生産量が必要となるので, 式 ( 3 )の制約条 件が設定される.

$$
p_{\mathrm{j}} \geq d_{\mathrm{j}}
$$

(iii)「生産材のトランプエレメント濃度」ミ「生産材のトラ ンプエレメント許容濃度」

供給材 $\mathrm{i}$ から生産材 $\mathrm{j}$ に配分する比率を $r_{\mathrm{ij}}$ としたとき式 (4)で示される, 生産材 $\mathrm{j}$ のトランプエレメントkの濃度 $q_{\mathrm{kj}}$ は, 需要 $\mathrm{j}$ のトランプエレメント $\mathrm{k}$ の許容濃度 $u_{\mathrm{kj}}$ 以下で なければならない. 従って, 式 (5)の条件式が設定できる.

$$
\begin{aligned}
& q_{\mathrm{kj}}=\sum_{i}\left(e_{\mathrm{ki}} \cdot s_{\mathrm{i}} \cdot r_{\mathrm{ij}}\right) / \sum_{i}\left(s_{\mathrm{i}} \cdot r_{\mathrm{ij}}\right) \\
& q_{\mathrm{kj}} \leq u_{\mathrm{kj}}
\end{aligned}
$$

(iv)「生産材のトランプエレメント濃度」ミ「生産材のトラ ンプエレメント必要濃度」

生産材 $\mathrm{j}$ のトランプエレメント $\mathrm{k}$ の濃度 $q_{\mathrm{kj}}$ は, 生産材 $\mathrm{j}$ のトランプエレメント必要濃度許容濃度 $l_{\mathrm{kj}}$ 以上でなければ ならない, 従って, 制約条件式は式 ( 6 ) となる.ただし,

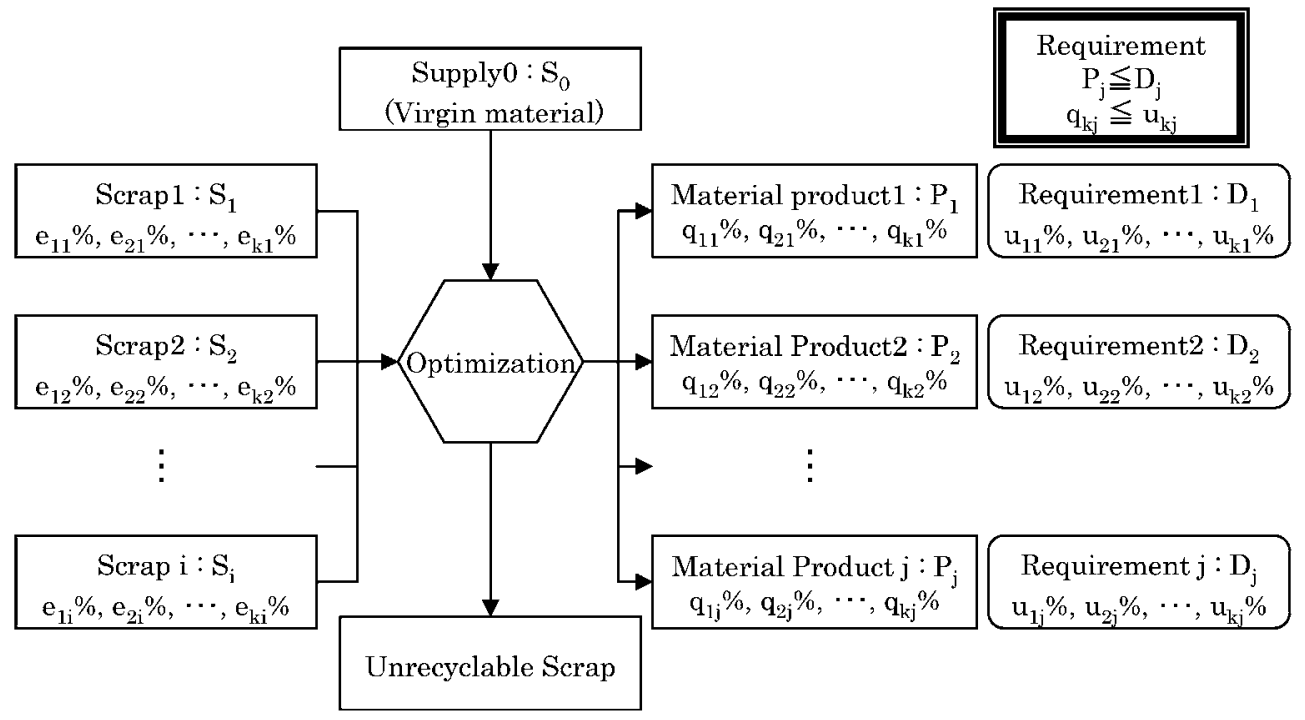

Fig. 1 Optimization. 
希釈に用いられるバージン材投入量の最小化が目的である場 合，こうした濃度下限值を制約条件にする必要はない。

$$
q_{\mathrm{kj}} \geq l_{\mathrm{kj}}
$$

\subsection{4 線形計画法の計算方法}

制約条件を表す連立 1 次不等式を満たす目的関数の最適 解を求める問題は,「線形計画」と呼ばれ, 図解法やシンプ レックス法で解くことができる. また, 制約条件の設定を行 えば最適解を算出できる, 線形計画法を解くためのソフトウ ェアも市販されている. 本研究でも市販のソフトウェア11,12) を用いた。

\section{4 仮想モデルへの適用}

バージン材を含む 4 つの供給材と 3 つの製品からなる仮 想モデルに線形計画法を適用する.このモデルでは, 希釈に 用いられるバージン材の使用量削減を目的とする.

\subsection{1 目的関数}

目的関数は, バージン材の供給量の最小化のみを考慮する ように設定した $($ 式 $(7))$ ．ここで， $s_{0}$ はバージン材供給量 である。

\section{4 .2 供給材の条件}

$$
f\left(s_{0}\right)=s_{0}
$$

考慮するトランプエレメントが $1 つ(\alpha)$ の場合 (ケース 1$)$, $2 つ(\alpha, \beta)$ の場合 (ケース 2$)$ 抢よび $3 つ(\alpha, \beta, \gamma)$ の場合 (ケー ス)のそれぞれに沶い, 最適化条件を求めた。 バージン材 以外の供給材 (スクラップ $\mathrm{A}$ ， スクラップ $\mathrm{B}$, スクラップ C) の供給量はいずれも $100 \mathrm{t}$ とした. それぞれのトランプエレ メント濃度を Table 1 に示す。

\subsection{3 生産材の条件}

希釈に用いられるバージン材の使用量削減を目的とするの で, 生産材のトランプエレメント許容濃度は, 上限值のみ設 定する (Table 2).

\subsection{4 解析結果(トランプエレメントがーつの場合)} ケース 1 に抢ける最適化の結果を Fig. 2 に示す.

図の左に供給材の供給量とトランプエレメント濃度を, 図

Table 1 Concentration of tramp element.

\begin{tabular}{cccc}
\hline & Scrap A & Scrap B & Scrap C \\
\hline Case 1 & $\alpha: 1.0 \%$ & $\alpha: 2.0 \%$ & $\alpha: 4.0 \%$ \\
\hline \multirow{2}{*}{ Case 2} & $\alpha: 1.0 \%$ & $\alpha: 2.0 \%$ & $\alpha: 4.0 \%$ \\
& $\beta: 5.0 \%$ & $\beta: 2.0 \%$ & $\beta: 2.0 \%$ \\
\hline \multirow{2}{*}{ Case 3 } & $\alpha: 1.0 \%$ & $\alpha: 2.0 \%$ & $\alpha: 4.0 \%$ \\
& $\beta: 5.0 \%$ & $\beta: 2.0 \%$ & $\beta: 2.0 \%$ \\
& $\gamma: 3.0 \%$ & $\gamma: 4.0 \%$ & $\gamma: 3.0 \%$ \\
\hline
\end{tabular}

Table 2 Requirement of concentration of alloy element.

\begin{tabular}{clll}
\hline & Product A & Product B & Product C \\
\hline Case 1 & $\alpha: 0.5 \%$ & $\alpha: 1.5 \%$ & $\alpha: 3.0 \%$ \\
\hline \multirow{2}{*}{ Case 2} & $\alpha: 0.5 \%$ & $\alpha: 1.5 \%$ & $\alpha: 3.0 \%$ \\
& $\beta: 4.0 \%$ & $\beta: 2.0 \%$ & $\beta: 1.0 \%$ \\
\hline \multirow{3}{*}{ Case 3} & $\alpha: 0.5 \%$ & $\alpha: 1.5 \%$ & $\alpha: 3.0 \%$ \\
& $\beta: 4.0 \%$ & $\beta: 2.0 \%$ & $\beta: 1.0 \%$ \\
& $\gamma: 2.0 \%$ & $\gamma: 2.0 \%$ & $\gamma: 0.5 \%$ \\
\hline
\end{tabular}

の右に生産材の生産量とトランプエレメント濃度を示してい る. 図の上にはバージン材の供給量, 図の下にリサイクルで きない供給材の量を示している。

ケース 1 の条件では, 少なくとも50tのバージン材の供 給が必要であり，リサイクルできない供給材も同量発生する ことが示されている.

このときの供給材の配分を Table 3 に示す.

スクラップ A は, 生産材 $\mathrm{A}$ に $50 \mathrm{t}$, 生産材 B に $50 \mathrm{t}$ 供給 される. スクラップ B は生産材 $\mathrm{B}$ と C にそれぞれ $50 \mathrm{t}$ 供給 されている. スクラップ C は, 生産材 $\mathrm{C} に 50 \mathrm{t}$ 供給してい るが, 残りの $50 \mathrm{t}$ は, トランプエレメントの許容濃度の条 件から，生産材で使用されていない.

また，バージン材は生産材 $\mathrm{A}$ 向けに供給され，スクラッ プAを希釈している.

\subsection{5 解析結果(トランプエレメントが 2 つある場合)}

考慮するトランプエレメントの数が 2 つの場合(ケース 2 ) の解析結果を Fig. 3 に示す。なお，トランプエレメント $\alpha$ に関する条件は，ケース 1 と同じである.

バージン材の必要供給量は, $118.8 \mathrm{t}$ となった.

供給材の配分状況 (Table 4) は, 供給材 (スクラップ) A に おける $\beta$ の濃度 $5 \%$ が制約となり, 生産材 $\mathrm{B}$ に打けるスク ラップ A 使用量が，ケース 1 に比べ減少していることがわ かる．このため，スクラップ A は, $37.5 \mathrm{t}$ がリサイクルさ れずに残ることになる. スクラップ B は, 生産材 B, C で全 て使用されるが，スクラップCについては，生産材 Cでの 使用量がケース 1 に比べ減少し，リサイクルできない量が 81.3 t に増大する.

結果として，リサイクルできないスクラップの量は 118.8

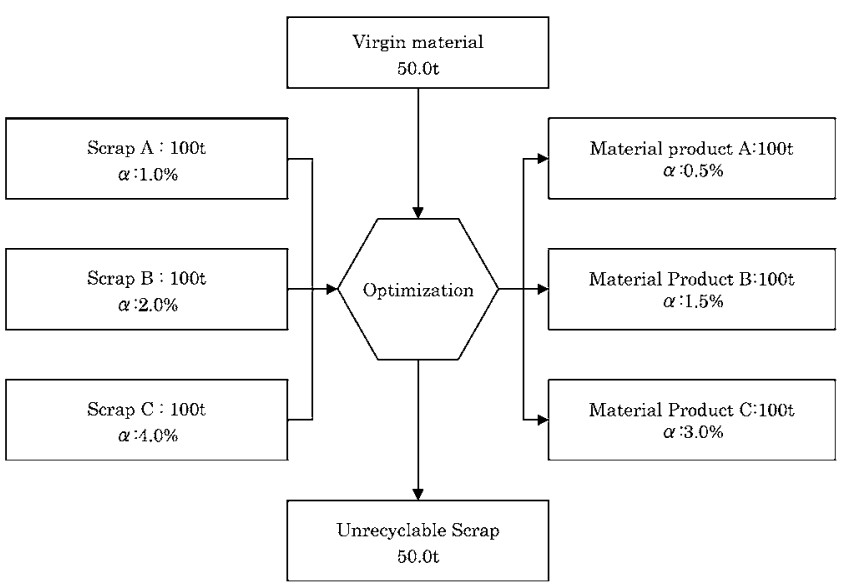

Fig. 2 Optimization Case 1.

Table 3 Optimization results : Case 1 .

\begin{tabular}{crrrrr}
\hline Supply & $\begin{array}{c}\text { Demand } \\
\text { A }\end{array}$ & $\begin{array}{c}\text { Product } \\
\text { B }\end{array}$ & $\begin{array}{c}\text { Product } \\
\text { C }\end{array}$ & $\begin{array}{c}\text { Unrecyclable } \\
\text { scrap }\end{array}$ & Total \\
\hline Scrap A & 50.0 & 50.0 & 0.0 & 0.0 & 100.0 \\
Scrap B & 0.0 & 50.0 & 50.0 & 0.0 & 100.0 \\
Scrap C & 0.0 & 0.0 & 50.0 & 50.0 & 100.0 \\
\hline Virgin & 50.0 & 0.0 & 0.0 & 0.0 & 50.0 \\
\hline Total & 100.0 & 100.0 & 100.0 & 50.0 & \\
\hline
\end{tabular}


tまで増大する.

\subsection{6 解析結果(トランプエレメントが 3 つある場合)}

考慮するトランプエレメントの数が 3 つの場合 (ケース 3 ) の解析結果を Fig. 4 に示す. な掞, トランプエレメント $\alpha$,

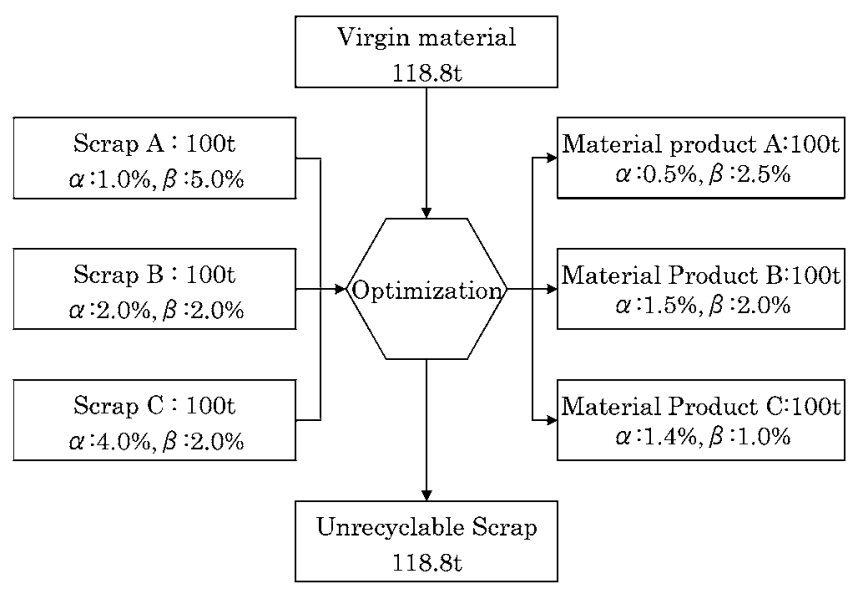

Fig. 3 Optimization Case 2.

Table 4 Optimization results : Case 2.

\begin{tabular}{|c|c|c|c|c|c|}
\hline Supply Demand & $\begin{array}{c}\text { Product } \\
\text { A }\end{array}$ & $\underset{\mathrm{B}}{\text { Product }}$ & $\underset{\mathrm{C}}{\text { Product }}$ & $\begin{array}{l}\text { Unrecyclable } \\
\text { scrap }\end{array}$ & Total \\
\hline Scrap A & 50.0 & 12.5 & 0.0 & 37.5 & 100.0 \\
\hline Scrap B & 0.0 & 68.8 & 31.3 & 0.0 & 100.0 \\
\hline Scrap C & 0.0 & 0.0 & 18.8 & 81.3 & 100.0 \\
\hline Virgin & 50.0 & 18.8 & 50.0 & 0.0 & 118.8 \\
\hline Total & 100.0 & 100.0 & 100.0 & 118.8 & \\
\hline
\end{tabular}

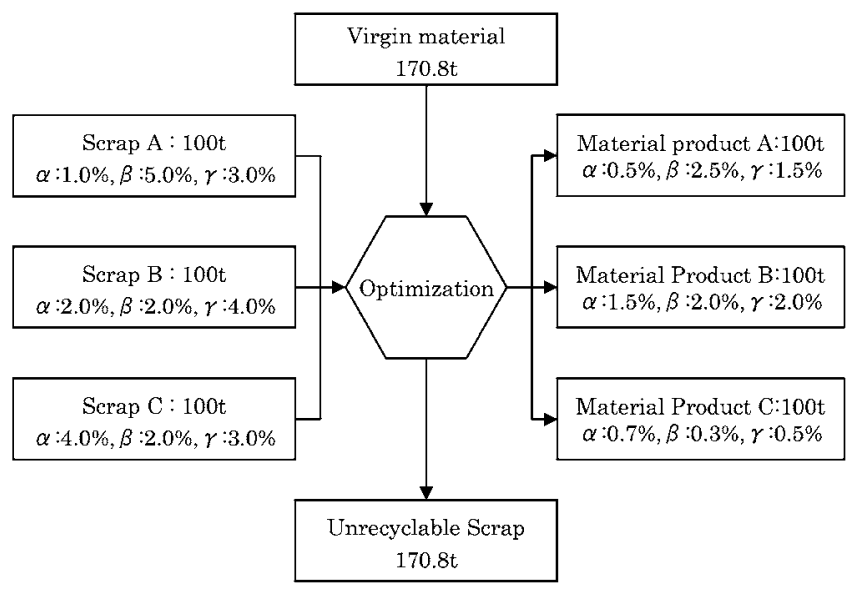

Fig. 4 Optimization Case 3.

Table 5 Optimization results : Case 3.

\begin{tabular}{crrrrr}
\hline Supply & $\begin{array}{c}\text { Demand } \\
\text { A }\end{array}$ & $\begin{array}{c}\text { Product } \\
\text { B }\end{array}$ & $\begin{array}{c}\text { Product } \\
\text { C }\end{array}$ & $\begin{array}{c}\text { Unrecyclable } \\
\text { scrap }\end{array}$ & Total \\
\hline Scrap A & 50.0 & 25.0 & 0.0 & 25.0 & 100.0 \\
Scrap B & 0.0 & 12.5 & 0.0 & 87.5 & 100.0 \\
Scrap C & 0.0 & 25.0 & 16.7 & 58.3 & 100.0 \\
\hline Virgin & 50.0 & 37.5 & 83.3 & 0.0 & 170.8 \\
\hline Total & 100.0 & 100.0 & 100.0 & 170.8 & \\
\hline
\end{tabular}

$\beta$ の条件は，ケース 2 と同じである.

バージン材の必要供給量は，170.8 t まで増大した。

ただし，配分状況（Table 5)は，スクラップの使用量が一 律に減少しているわけではない。スクラップ A と C の使用 量は, ケース 2 に比べ増大している.

\section{3. 日本国内のアルミニウムリサイクルフローの最適 化}

線形計画法によるリサイクルフロー最適化モデルを, 2003 年度の日本におけるアルミニウムのリサイクルフロー に適用した。

\section{1 日本におけるアルミニウムの需給構造}

アルミニウムは，広くリサイクルが行われている金属材料 の一つである. 用途に応じて様々な元素が添加され，多くは 合金として用いられているため, 回収スクラップからリサイ クル材 (再生地金)を製造する祭には，合金成分の調整が欠か せない，一方，それらの合金成分の多くや，使用済久製品か ら回収する時に混入する一部の元素は，混入後に除去するこ とは極めて困難とされる. こうした混入成分の除去技術の開 発も行われている13)が，主として経済的理由から実用化に 至ったものは少なく，リサイクル時の成分調整は，回収久ク ラップからの異物除去の徹底と混合 (希釈)により行われるの が一般的である。

一方，我が国に打けるアルミニウムの需給構造は次のよう な特徵を有する. (1)原料の約 $57 \%$ がバージン材(新地金)で ある。(2)新地金の $99 \%$ 以上を海外からの輸入に依存してい る. (3)再生地金の $75 \%$ 以上は，鋳物，ダイカストとして製 品化される5).

ここで，鋳物，ダイカスト製品の大半は自動車であり，そ の国内生産量の約半数は輸出される14)ことを考慮すると, 日本におけるアルミニウムのマテリアルフローは, 添加元 素, 混入元素の少ない純アルミニウム輸入し, それに合金元 素を添加して使用し, 国内のリサイクル過程で合金元素の濃 度を高め, 合金元素の濃度が高い状態で輸出するという構造 になっていると言うことができる.

そこで，日本におけるアルミニウムのリサイクルフローに 線形計画法を適用し，その最適化による新地金使用量の削減 可能性を検討した.

\section{2 データの準備}

\subsection{1 日本国内のアルミニウムのリサイクルフローのモデ ル化}

アルミニウムのリサイクルフローは, 供給材を 23 種(新 地金, 老廃スクラップ材 8 種, 加工スクラップ材 14 種), 製品を 16 種に分類し，トランプエレメントは， $\mathrm{Si}, \mathrm{Fe}, \mathrm{Cu}$, Mnの 4 元素として解析した.

本研究では, 国内で回収されるスクラップ材と, そのスク ラップ材から製造されるリサイクル材(再生地金)のトランプ エレメント濃度は等しいものとし, 新地金以外の供給材 (老 廃スクラップ材, 加工スクラップ材)のトランプエレメント 
濃度は, 国内で回収されるスクラップ材のトランプエレメン ト濃度推定值 ${ }^{15)}$ の值を用いた。新地金のトランプエレメン ト濃度は 0 とした。

また，国内で製造される再生地金と海外から輸入する再生 地金も区別せず，輸入も含めた再生地金供給量 (2003 年度統 計值) と, 国内回収スクラップの回収量が一致するように, スクラップの国内回収量に一定の割合を乗じた.

新地金以外の供給材 (老廃スクラップ材, 加工スクラップ 材)のトランプエレメント濃度と供給量を Table 6 に示す.

需要側のトランプエレメント許容濃度は, JIS に規格され る化学成分の上限值を用い, 最低必要量(下限值)は考慮しな かった。需要量は，2003 年度の統計值 ${ }^{16,17)}$ を用いた (Table 7).

\subsection{2 目的関数}

アルミニウムの再生地金の製造に要するエネルギーは，新 地金製造に要するエネルギーの $3 \%$ 以下といわれている3). アルミニウム新地金の消費を低減することは，エネルギー消 費量および地球温暖化などの環境負荷に大きく貢献する．そ こで, 本研究では, バージン材使用量の最小化を目的関数と した. 従って，目的関数は式 $(7)$ で示される.

Table 6 Scrap supply and Tramp elements concentration.

\begin{tabular}{|c|c|c|c|c|c|}
\hline \multirow{2}{*}{ Source } & \multirow{2}{*}{$\underset{(\mathrm{kt})}{\text { Supply }}$} & \multicolumn{4}{|c|}{$\begin{array}{l}\text { Tramp elements } \\
\text { concentration }(\%)\end{array}$} \\
\hline & & $\mathrm{Si}$ & $\mathrm{Fe}$ & $\mathrm{Cu}$ & $\mathrm{Mn}$ \\
\hline \multicolumn{6}{|l|}{ Obsolete scrap } \\
\hline Fabricated metal & 109 & 0.760 & 0.410 & 0.340 & 0.100 \\
\hline Food (including recycled can) & 289 & 0.290 & 0.590 & 0.220 & 1.140 \\
\hline General machinery & 14 & 6.120 & 0.830 & 2.030 & 0.330 \\
\hline $\begin{array}{l}\text { Electrical communication } \\
\text { machinery }\end{array}$ & 60 & 3.210 & 0.610 & 1.000 & 0.230 \\
\hline Transportation (mill products) & 89 & 1.790 & 0.450 & 0.260 & 0.160 \\
\hline Engine & 476 & 9.970 & 1.180 & 3.700 & 0.500 \\
\hline Building and construction & 191 & 0.610 & 0.380 & 0.120 & 0.170 \\
\hline Other & 78 & 3.050 & 0.850 & 1.310 & 0.550 \\
\hline \multicolumn{6}{|l|}{ Industrial scrap } \\
\hline 1000 series & 52 & 0.320 & 0.380 & 0.090 & 0.050 \\
\hline 2000 series & 3 & 0.780 & 0.730 & 4.940 & 0.810 \\
\hline 3003 & 4 & 0.600 & 0.700 & 0.200 & 1.500 \\
\hline 3004 & 48 & 0.300 & 0.700 & 0.250 & 1.500 \\
\hline other 3000 series & 31 & 0.600 & 0.750 & 0.280 & 1.110 \\
\hline 4000 series & 3 & 13.500 & 1.000 & 1.300 & 0.000 \\
\hline 5052 & 24 & 0.250 & 0.400 & 0.100 & 0.100 \\
\hline 5182 & 21 & 0.200 & 0.350 & 0.150 & 0.500 \\
\hline other 5000 series & 17 & 0.290 & 0.310 & 0.130 & 0.560 \\
\hline 6061 & 8 & 0.800 & 0.700 & 0.400 & 0.150 \\
\hline 6063 & 237 & 0.600 & 0.350 & 0.100 & 0.100 \\
\hline other 6000 series & 14 & 0.960 & 0.500 & 0.230 & 0.630 \\
\hline 7000 series & 4 & 0.180 & 0.210 & 2.080 & 0.160 \\
\hline 8000 series & 14 & 0.230 & 1.500 & 0.050 & 0.000 \\
\hline
\end{tabular}

\section{3 シナリオ解析}

日本国内に抢ける現在のアルミニウムの需給構造は, 需要 がスクラップ材の供給量を大きく上回っているため, スクラ ップ材の余剰は生じていない. そこで, スクラップ材の供給 量が増加したり，鋳物・ダイカストの国内需要が減少する 等, トランプエレメント濃度の高いスクラップ材の流通量が 増えるケースを想定したシナリオ解析を行い, 国内のリサイ クルフローの許容し得る, 将来の需給構造の変化の範囲を考 察した。 また, 感度解析も行った.

\subsection{1 再生地金による新地金代替可能性の検討}

（i）廃自動車から製造する再生地金の使用量の増加を想定 したシナリオ解析

陸運分野から排出されるスクラップ材のうちエンジンブロ ック等の鋳物, ダイカスト由来のもの(廃自動車鋳物)の供給 量(同等成分の輸入再生地金を含む) が増加した場合の新地金 代替最大可能量を算出した。 また, 感度解析を行った.

(ii) 廃建材から製造する再生地金の使用量の増加を想定し

\section{たシナリオ解析}

土木建築分野から排出されるスクラップ(廃建材)の供給量 (同等成分の輸入再生地金を含む) が増加した場合の新地金代 替最大可能量を算出した。 また，感度解析を行った。

(iii) 鋳物, ダイカストの国内需要縮小

現在のアルミニウムの需給構造では, トランプエレメント は, 鋳物, ダイカスト製品に含有され海外に輸出されてい る.そこで, 生産拠点の海外移転等による鋳物, ダイカスト の国内需要縮小があった場合の新地金必要量を考察した.

具体的には, 鋳物, ダイカストの需要を縮小(総需要も縮 小)させ, 利用できないスクラップが発生する限界点を求め た.

Table 7 Tramp elements concentration upper limit and Demand.

\begin{tabular}{lccccr}
\hline & $\mathrm{Si}$ & $\mathrm{Fe}$ & $\mathrm{Cu}$ & $\mathrm{Mn}$ & Demand \\
\hline 1000 series & 0.325 & 0.381 & 0.086 & 0.048 & 435519 \\
\hline 2000 series & 0.779 & 0.726 & 4.935 & 0.810 & 22624 \\
\hline 3003 & 0.600 & 0.700 & 0.200 & 1.500 & 32950 \\
\hline 3004 & 0.300 & 0.700 & 0.250 & 1.500 & 270818 \\
\hline other 3000 series & 0.600 & 0.748 & 0.275 & 1.112 & 193443 \\
\hline 4000 series & 13.500 & 1.000 & 1.300 & 0.000 & 28492 \\
\hline 5052 & 0.250 & 0.400 & 0.100 & 0.100 & 150440 \\
\hline 5182 & 0.200 & 0.350 & 0.150 & 0.500 & 117461 \\
\hline other 5000 series & 0.288 & 0.311 & 0.130 & 0.562 & 113931 \\
\hline 6061 & 0.800 & 0.700 & 0.400 & 0.150 & 30150 \\
\hline 6063 & 0.600 & 0.350 & 0.100 & 0.100 & 802461 \\
\hline other 6000 series & 0.958 & 0.496 & 0.229 & 0.628 & 55507 \\
\hline 7000 series & 0.182 & 0.215 & 2.076 & 0.157 & 37107 \\
\hline 8000 series & 0.225 & 1.500 & 0.050 & 0.000 & 113837 \\
\hline Castings (AC2B) & 7.000 & 1.000 & 4.000 & 0.500 & 408770 \\
\hline Die- & 12.000 & 1.300 & 3.500 & 0.500 & 867464 \\
\hline
\end{tabular}




\section{4. 解析結果と考察}

\section{1 再生地金による新地金代替可能性のシナリオ解析結果}

シナリオ解析の結果を Table 8 に示す.

\subsection{1 廃自動車から製造する再生地金の使用量の増加を想 定したシナリオ解析}

廃自動車鋳物の回収量を増やす，あるいは同等の成分を有 する再生材の輸入を増やした場合，2003 年度の新地金使用 量を $1290 \mathrm{kt}$ まで削減可能という結果を得た(Table 8 Case (i))。これは, 2003 年度実績值の $2409 \mathrm{kt}$ の約 $54 \%$ に相当 する，言い換えると，新地金使用量のうち，その約 $46 \%$ ま では，廃自動車鋳物から製造する再生地金で代替できるとい うことがわかった。

このときの感度解析の結果を Fig. 5 に示す. グラフの高 さは，投入するスクラップのトランプエレメント濃度が， 1 $\mathrm{ppm}$ 変化した場合の新地金投入量の変化量を示しており, 廃自動車鋳物の供給に拈りる $\mathrm{Cu}$ の感度が高くなっている. 以下で，この理由について考察する.

投入する廃自動車鋳物を最も多く消費するのはダイカスト である、そこで，廃自動車鋳物のトランプエレメント濃度と ダイカストの許容するトランプエレメント濃度を比較する と, ダイカスト許容濃度に対する廃自動車鋳物のトランプエ レメント濃度の割合は，それぞれ， $\mathrm{Si}: 83 \% ， \mathrm{Fe}: 91 \%$ ， $\mathrm{Cu}: 106 \%, \mathrm{Mn}: 100 \%$ であった。このことから, 廃自動車 鋳物の $\mathrm{Cu}$ 濃度の削減により，ダイカスト側の許容值を超え る $\mathrm{Cu}$ 濃度を希釈するために消費されている新地金の消費を

Table 8 Scenario analysis results.

\begin{tabular}{ccc} 
& & (unit : kt) \\
\hline Added source & $\begin{array}{c}\text { Case (i) } \\
\text { Engine scrap }\end{array}$ & $\begin{array}{c}\text { Case (ii) } \\
\text { Building \& Construc- } \\
\text { tion scrap }\end{array}$ \\
\hline Added amount of scrap supply & 602 & 1108 \\
\hline Requirement of Virgin Material & 1293 & 766 \\
\hline
\end{tabular}

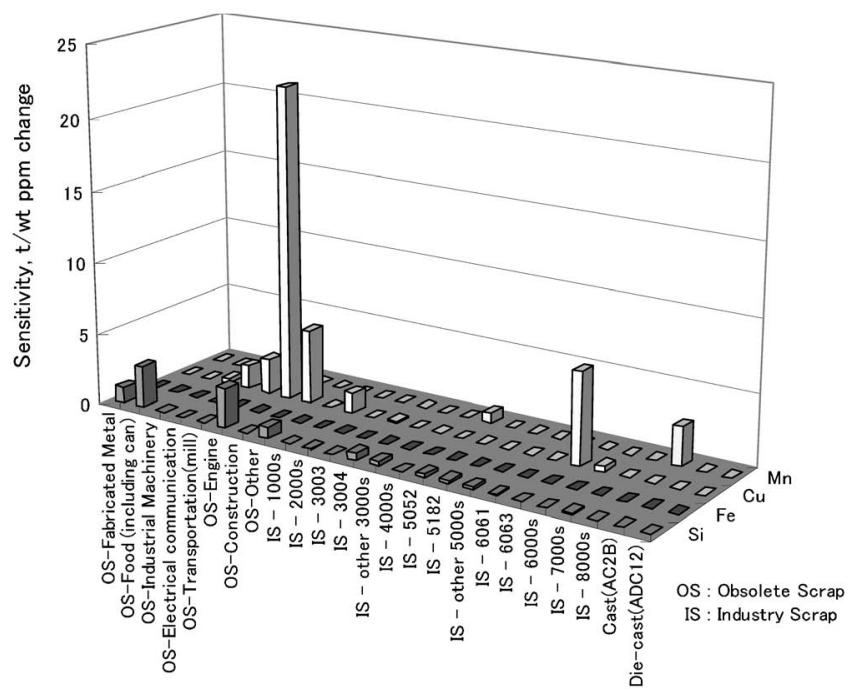

Fig. 5 Sensitivity analysis results (1).
削減することが可能になると考えられる.

\subsection{2 廃建材から製造する再生地金の使用量の増加を想定 したシナリオ解析}

廃建材のみで代替した場合は，新地金使用量を $768 \mathrm{kt}$ ま で削減可能という結果を得た(Table 8 Case(ii))。これは, 2003 年度実績值の約 $32 \%$ に相当する.すなわち新地金の約 $68 \%$ までは廃建材から製造する再生地金で代替可能という 結果を得た.

このときの感度解析の結果を Fig. 6 に示す.

廃建材の供給における $\mathrm{Mn}$ の感度が高い。以下でこの理 由を考察する。

投入する廃建材を最も多く消費するのは 6063 である．廃 建材のトランプエレメント濃度と 6063 のトランプエレメン 卜許容濃度を比較すると, $\mathrm{Si}: 102 \%, \mathrm{Fe}: 109 \%, \mathrm{Cu}$ : 120\%，Mn：170\%と，廃建材に抢ける Mnの濃度が， 6063 の許容值を大きく上回っていることがわかる，このことか ら，廃建材で新地金を代替する場合には，Mnの濃度を下げ ることで，新地金必要量を削減できると考えられる。

\section{2 鋳物, ダイカストの国内需要縮小のシナリオ解析結果}

鋳物ダイカストの国内需要が $50 \%$ まで縮小しても，リサ イクル不可能なスクラップ材は発生しなかった. 鋳物, ダイ カストの許容するトランプエレメント濃度には，十分余裕が あることが確認できた。

\section{5. 結言}

本研究では, 金属材料のリサイクルフローに線形計画法を 適用し, 複数のトランプエレメントを考慮したリサイクルフ ローの最適化手法を開発した.

また，日本国内のアルミニウムのリサイクルフローに本手 法を適用し，需要の変化に対する新地金の最低必要量を求め た。

その結果，廃自動車鋳物の供給量を増加した場合，2003

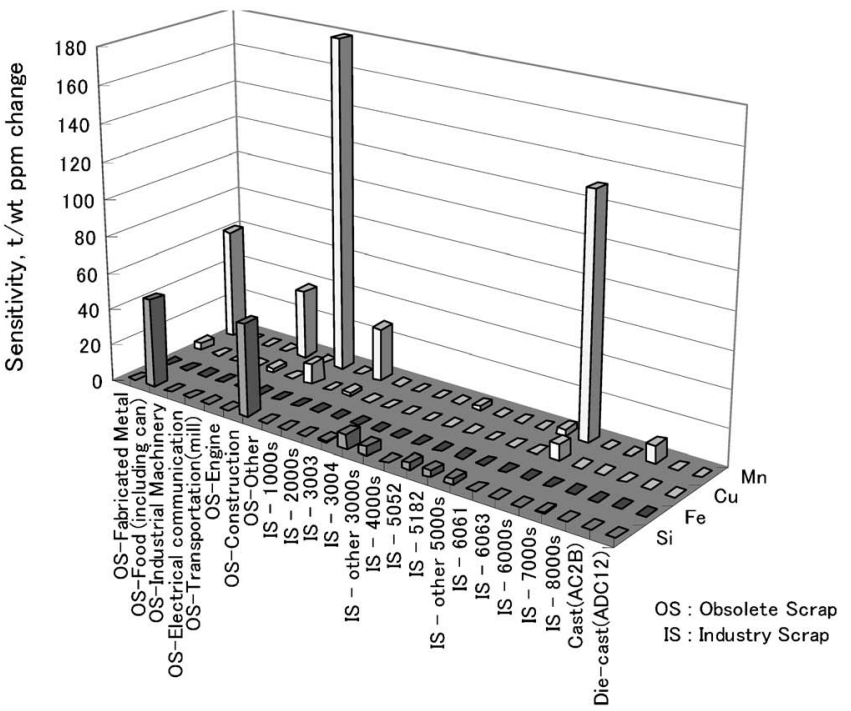

Fig. 6 Sensitivity analysis results (2). 
年度実績比で約 $46 \%$ まで新地金を廃自動車鋳物から製造し た再生地金で代替できることがわかった。

新地金の代替材料として，廃建材を用いた場合は，約 68\%の新地金を代替できることがわかった.

をた，感度解析を行った結果，廃自動車鋳物による新地金 代替を進める場合は，廃自動車鋳物中の $\mathrm{Cu}$ の濃度が新地金 の使用量に大きく影響することがわかった．同様に廃建材に よる新地金代替を進める場合は，廃建材中の Mnの濃度の 感度が高いことがわかった.

また，高いトランプエレメント濃度で輸出されている鋳 物, ダイカストの需要が $50 \%$ まで減少しても, リサイクル できないアルミニウムスクラップが発生することはないこと が確認できた.

本研究は, 平成 17-18 年度科学研究費補助金 (若手研究 (B)：循環型社会における素材リサイクル最適化モデルの構 築)の支援を受けて実施した。ここに謝意を表する.

\section{文献}

1) K. Kakudate, Y. Adachi and T. Suzuki: Tetsu-to-Hagané 86 (2000) 837.

2) I. Daigo, D. Fujimaki, Y. Matsuno and Y. Adachi: Tetsu-toHagané 91 (2005) 171-178.

3) K. Okuma: Kinzoku 66(1996) 117

4) T. Nakamura: Materia Japan 35 (1996) 1290.

5) The Japan Institute of Light Metals: Aluminium no kanzen recycle system kochiku ni mukete (2005).

6) H. Tatsumi and K. Matsuda: Pinch Technology, (The Energy Conservation Center, Japan, Tokyo, 2002).

7) J. Jacob, H. Kaipe, F. Couderc and J. Paris: Chem. Eng. Comm. $\mathbf{1 8 9}(2002) 184$.

8) Y. Matsuno, I. Daigo and Y. Adachi: Tetsu-to-Hagané 91 (2005) 127-134.

9) K. Kanaya: Korenarawakaru Saitekika Sungaku (2005) 159.

10) G. B. Dantzig: Linear programming and extensions, (Princeton University Press, Princeton, 1963).

11) K. Ohno, T. Ito and T. Tamura: Excel niyoru shisutemu saitekika, (CORONA Publishing Co., ltd., Tokyo, 2001).

12) KBC Process Technology Ltd.: WaterTarget.

13) T. Ohzono, M. Ohtaki and M. Yanagawa: Kinzoku 74(2004) 1172

14) Japan Automobile Manufacturers Association, Inc.: The Motor Industry of Japan (2005).

15) H. Hatayama, H. Yamada, I. Daigo, Y. Matsuno and Y. Adachi: J. Japan Inst. Metals 70(2006) 975-980.

16) Japan Aluminium Association: Aluminium Statistics in Japan (2003).

17) Ministry of Economy, Trade and Industry: Yearbook of Iron and Steel, Non-ferrous Metals, and Fabricated Metals Statistics (2004). 